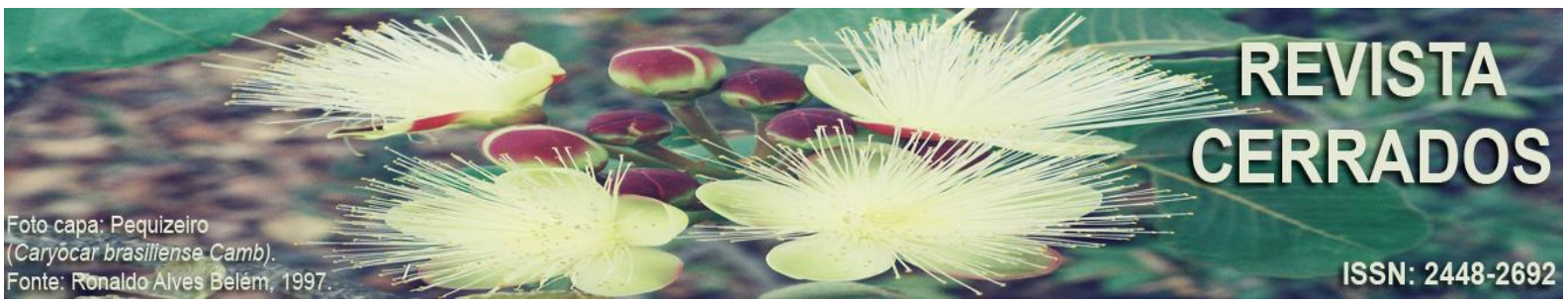

\title{
MORFOLOGIA URBANA DE JANAÚBA/MG
}

\author{
URBAN MORPHOLOGY OF JANAÚBA CITY / MG
}

\author{
MORFOLOGÍA URBANA DE JANAÚBA / MG
}

\author{
Vivian Mendes Hermano \\ Universidade Estadual de Montes Claros - UNIMONTES \\ E-mail: <hermanovivian@gmail.com>.
}

\begin{abstract}
Resumo
A morfologia contribui para os estudos sobre cidades, em especial aqueles interessados no entendimento da conformação e da funcionalidade. Uma importância primaz é destacar a relação entre os agentes naturais e sociais na formação da paisagem. Nesse sentido, este estudo tem como objetivo central analisar a morfologia urbana de Janaúba/MG, e, como fins específicos: detalhar a estrutura urbana local,pela identificação de seu sítio e tecido; contribuir com os estudos urbanos locais e regionais; exemplificar um conjunto metodológico que possa ser desenvolvido em outros espaços da região do Norte de Minas. A metodologia aplicada se pautou na análise geossistêmica do sítio urbano local, enfatizando os aspectos climático, geomorfológico, hidrológico e vegetacional, e na identificação e no zoneamento do tecido urbano, segundo modelo de Amorim Filho (2005). Os resultados indicam que o quadro natural da cidade foi e é agente interventor positivo da organização e da expansão da cidade; o tecido, em sua conformação, é orientado pela presença dos equipamentos públicos, com forte influência das vias. As categorias do modelo foram reconhecidas, mas se registraram singularidades. A partir dos resultados, identificaram-se traços do avanço econômico e demográfico, associados à falta do planejamento urbano, resultando em uma estrutura, em parte, desequilibrada.
\end{abstract}

Palavras-chave: Morfologia Urbana; Sítio; Tecido; Janaúba/MG.

\begin{abstract}
Morphology contributes to studies on cities, particularly those interested in understanding conformation and functionality. A major importance is to highpoint the connection between natural and social agents in landscape formation. Thus, this study aims to analyze urban morphology of Janaúba city / MG. As specific purposes: detail the local urban structure, by identifying its site and fabric; contribute to local and regional urban studies; exemplify a
\end{abstract}


methodological set that can be developed in other places of the North of Minas Gerais. Applied methodology based on local urban site geosystemic analysis, emphasized the climatic, geomorphological, hydrological and vegetative aspects, identified and zoned urban fabric, according to Amorim Filho (2005) model. Results indicate that the natural representation of the city was and is a positive intervening agent of organization and expansion of the city; fabric, in its conformation, is oriented by the presence of public equipments, with strong influence of the thoroughfare. Model categories were recognized, but singularities were recorded. From the results, traces of economic and demographic advances were identified, associated to the lack of urban planning, resulting in a structure, in part, unstable.

Keywords: Urban Morphology; Site; Tissue; Janaúba city / MG.

\section{Resumen}

La morfología contribuye a los estudios sobre ciudades, en especial aquellos interesados en el entendimiento de la conformación y funcionalidad. Es primordial destacar la relación entre los agentes naturales y sociales en la formación del paisaje. En este sentido, este estudio tiene como objetivo central analizar la morfología urbana de la ciudad de Janaúba / MG, y, como fines específicos: detallar la estructura urbana local, por la identificación de su sitio y tejido; contribuir con los estudios urbanos locales y regionales; ejemplificar un conjunto metodológico que pueda ser desarrollado en otros espacios de la región del Norte de Minas. La metodología aplicada se basó en el análisis geosistémico del sitio urbano local, enfatizando los aspectos climático, geomorfológico, hidrológico y vegetacional, y en la identificación y zonificación del tejido urbano, según modelo de Amorim Filho (2005). Los resultados indican que el cuadro natural de la ciudad fue y es agente interventor positivo de la organización y expansión de la ciudad; El tejido, en su conformación, está orientado por la presencia de los equipamientos públicos, con fuerte influencia de las vías. Las categorías del modelo fueron reconocidas, pero se registraron singularidades. A partir de los resultados, se identificaron rasgos del avance económico y demográfico, asociados a la falta de planificación urbana, resultando en una estructura, en parte, desequilibrada.

Palabras clave: Morfología Urbana; Sitio; Tejido; Ciudad de Janaúba / MG.

\section{INTRODUÇÃO}

O entendimento e a descrição do espaço interno da cidade ressaltam a importância da análise das especificidades de cada lugar, consequência da forma de organização da comunidade envolvida, sendo essa estruturação fruto da produção social. Entretanto, os fatores naturais não devem ser totalmente negligenciados, já que, de alguma maneira, esses elementos acabam por influenciar e até mesmo determinar certos padrões da conformação urbana. Nesse contexto, destaca-se que, por meio do estudo morfológico, é possível 
compreender o processo de formação da cidade, sua estrutura atual, identificando os fatores de influência natural, verificando a presença ou não do planejamento.

Essa temática possui certa relevância para a compreensão do processo de expansão urbana, em especial nas áreas do interior, como as da região do Norte de Minas, localizadas na bacia e nas subbacias do Rio São Francisco. Esses locais, mais recentemente, modernizaram-se; ao mesmo tempo, experimentam um início de densificação de seu sistema urbano, fortalecendo uma rede ainda carente de estudos específicos que possam contribuir para o seu desenvolvimento.

Isso posto, o objetivo central deste estudo foi analisar a morfologia urbana de Janaúba/MG, e teve, como fins específicos: detalhar a estrutura urbana local, por meio da identificação de seu sítio e tecido; contribuir para os estudos urbanos locais e regionais; exemplificar um método de pesquisa morfológico que possa ser aplicado a outras realidades locais. Destaca-se que este estudo é resultado parcial da Tese de Doutorado da autora.

É importante ressaltar que o município de Janaúba/MG possui, segundo o IBGE uma área de $2.151,7 \mathrm{Km}^{2}$, à margem esquerda do rio Gorutuba, localizado na mesorregião do Norte de Minas. É cortado pelas rodovias BR 122, que a liga a região sudeste a nordeste, e a MG 401 que a interliga à região ao projeto Jaíba. Para o IBGE, a cidade de Janaúba/MG é um centro subregional; para os autores que residem na própria região, como Hermano (2006, 2016), Pereira (2007) e França e Queiroz (2013), esta cidade exerce importante papel de centralização e polarização na rede regional.

Para refletir sobre o espaço intraurbano da cidade tema, o texto está organizado em seções que buscam contextualizar teórica e geograficamente o tema e a área de estudo. No primeiro momento, apresenta-se o conjunto metodológico aplicado; a seguir, a revisão teórica dos temas morfologia urbana, sítio e tecido. Nas seções subsequentes, delimita-se a área de estudo e se procede com a identificação, a descrição e a análise do sítio e do tecido urbano de Janaúba/MG. Por fim, busca-se apresentar a interrelação dos fatores analisados e as reflexões sobre a organização e a estruturação da cidade em foco.

\section{METODOLOGIA}

Para a compreensão do espaço interno da cidade, analisaram-se os seguintes elementos da morfologia: sítio e tecido urbano. O conceito de sítio urbano adotado considera 


\section{HERMANO, V. M. \\ Morfologia urbana de Janaúba/MG}

a base estrutural na qual se insere as relações urbanas. São considerados aspectos da paisagem que podem ser parcialmente imutáveis, mas que, por outro lado, em especial a partir da intensificação e do adensamento humano, se transformam.

Esse sítio foi identificado a partir da análise dos documentos (relatórios de secretarias como as de Educação e de Obras) obtidos junto à Prefeitura Municipal de Janaúba (PMJ), e também pela pesquisa de campo, para a identificação, nessa paisagem, de elementos como a hidrografia, a geomorfologia e a vegetação. No que se refere ao tecido urbano, inferese que é formado pelo sistema viário, pelo padrão do parcelamento do solo, pela aglomeração e pelo isolamento das edificações, assim como pelos espaços livres. O tecido de cidade é dado por edificações, ruas, quadras e lotes, parques, praças e monumentos nos seus mais variados arranjos, nos espaços vagos e na forma da organização da cidade.

Para a delimitação do tecido urbano, parte-se de informações coletadas na PMJ, em especial as leis municipais $\mathrm{n}^{\circ} 1744$, de 2007, e $\mathrm{n}^{\circ} 2104$, de 2015, que dispõem sobre o Plano Diretor Municipal (PDM). Na determinação da evolução temporal do tecido, utiliza-se como base analítica a contextualização histórica da cidade, que identifica a sequência de implantação dos principais equipamentos públicos, em especial as vias, identificados nos estudos de Hermano (2016).

As zonas urbanas da cidade de Janaúba/MG são definidas segundo Amorim Filho (2005), que estruturou um modelo esquemático para a identificação das zonas de uma cidade média. Neste artigo, esse modelo foi adotado com a função de permitir uma classificação das diferentes áreas da cidade, afim de estruturar o desenvolvimento de uma análise comparativa entre a realidade e um referencial conhecido.

O modelo é descrito por Amorim Filho (2005) da seguinte forma:

- Zona Central: Centro principal bem definido funcionalmente (forte presença de equipamentos "raros", de alcance regional); diferenciação funcional interna; paisagem e morfologia típicas (construções em altura; maior densidade de construções; forte movimento de veículos e de pessoas, animação); função residencial superada pelas funções terciárias; centro com polarização pelo menos microrregional, podendo alcançar o nível regional de polarização;

- Zona Pericentral: Extensa espacialmente; função residencial predominante; presença de subcentros especializados ou polifuncionais (estes últimos pequenos), ao longo dos eixos, de praças e de entroncamentos; diferenciação morfológica e paisagística em função de diferenças sócio-econômicas; presença de equipamentos especiais como hospitais, universidades, casernas, estações rodoviárias e ferroviárias, etc.;

- Zona Periférica: De dois tipos: contínua (como prolongamento da zona pericentral) e descontínua, ou polinuclear, formada por loteamentos (unidades organizadas) ou "vilas" (desorganizadas e, em certas regiões, verdadeiras 
favelas); presença de subcentros polifuncionais bem modestos (comércio e serviços de vizinhança) e de alguns subcentros especializados; extensão proporcional ao nível hierárquico e tamanho da cidade;

- Zona Periurbana: Presença de uma zona de transição urbano rural mais ou menos extensa, e que se confunde, nas imediações da cidade, com a periferia polinuclear e descontínua; presença de alguns equipamentos terciários pontuais; aumento das casas de campo, de clubes campestres e hotéis-fazenda; diminuição das fazendas e aumento das pequenas propriedades com produtos para a cidade média. (AMORIM FILHO, 2005, p. 61).

A delimitação e a qualificação das zonas da cidade identificam sua estrutura atual e permitem elaborar reflexões sobre seu processo de formação. Para sua identificação, foram utilizados, como técnicas, o trabalho de campo e o registro fotográfico. O levantamento permitiu uma classificação pautada na leitura da paisagem urbana, que não é uma delimitação precisa, possuindo certo grau de subjetividade, mas que indica a feição geral da cidade e de suas repartições.

Em função da presença de determinado "padrão" de paisagem em cada zona, o registro fotográfico é amostral. O trabalho icnográfico identificou nas paisagens urbanas modalidades de uso e de ocupação do solo, e as feições mais recorrentes foram: comercial, residencial, área verde, terreno vago e áreas com presença dos equipamentos públicos. Para a representação e o destaque de cada elemento nas figuras, adotou-se a simbologia apresentada no quadro um.

\section{Quadro1: Itens avaliados na paisagem urbana de Janaúba/MG}

\begin{tabular}{|l|l|}
$\longrightarrow \longrightarrow$ & Comercial \\
\hline$\longrightarrow$ & Residencial \\
$\longrightarrow \longrightarrow$ & Área verde \\
\hline$\longrightarrow$ & Terreno vago \\
\hline & Equipamento público \\
\hline
\end{tabular}

Fonte: Elaborado pela autora.

Para a elaboração dos mapas, foram adquiridas as bases cartográficas (limites municipais, sedes dos municípios, rodovias federais e estaduais e ferrovia) nos sítios do Instituto Brasileiro de Geografia e Estatística (IBGE) e do Departamento Nacional de Infraestrutura de Transportes (DNIT). A elaboração dos mapas de escala mais ampla (área urbana) foi subsidiada por trabalhos de campo, nos quais foi possível observar com maior detalhe as feições urbanas em destaque (áreas alagáveis e vazios urbanos). 
A apropriação de imagens do aplicativo Google Earth ${ }^{\mathbf{T M}}$ pró (disponibilizadas pela Digital Globe, 2012) foi útil na delimitação da área urbanizada de Janaúba/MG e de Nova Porteirinha, em 2013. Os perfis topográficos também foram elaborados a partir de ferramentas disponíveis no aplicativo Google Earth ${ }^{\mathbf{T M}}$ pró. Todos os produtos cartográficos foram elaborados por meio da plataforma do aplicativo $\operatorname{ArcGIS}{ }^{\mathbf{T M}}$ 9.3, o que possibilitou melhor apresentação na preparação dos layouts.

\section{A importância dos estudos morfológicos}

$\mathrm{Na}$ Geografia, há pesquisas que abordam o espaço interno da cidade fundamentadas em análises da representação dos elementos constituintes da morfologia, como o plano e a evolução; as relações do plano com o sítio urbano; a fisionomia urbana; a densidade da ocupação; a identificação de áreas morfologicamente homogêneas; a heterogeneidade das formas. Dollfus (1982) destacou que as cidades se definem no espaço geográfico por sua posição (também chamada situação) e por seu sítio. Para ele, tratam-se de duas noções distintas, ligadas a escalas diferentes. O autor ressalta a importância do estudo interno da cidade como ferramenta de sua definição.

Uma publicação nacional relevante sobre o tema foi o livro $O$ espaço intraurbano no Brasil, de Villaça (1998). Essa obra propõe algumas abordagens sobre o espaço interno da cidade, mas não chega a definir uma metodologia de pesquisa. Seus estudos estão baseados em seis metrópoles brasileiras. Segundo o pesquisador, o espaço interno pode ser definido da seguinte forma:

\footnotetext{
O espaço intra-urbano é estruturado fundamentalmente pelas condições de deslocamento do ser humano, seja enquanto portador da mercadoria força de trabalho, seja enquanto consumidor, exatamente daí vem o poder estruturador intraurbano das áreas comerciais e de serviços, a começar pelo próprio centro urbano. $\mathrm{O}$ espaço urbano é determinado pelas condições de produção e reprodução do capital, em especial o capital humano, gerando os deslocamentos internos e a organização das moradias, entre outros. (VILLAÇA, 1998, p. 20).
}

A citação esclarece que, para o entendimento das formas urbanas (bairros, direções de crescimento, forma da mancha urbana, verticalização, densidade etc.), é indispensável considerar as relações de determinado ponto, ou conjunto de pontos, com todos os demais pontos do espaço urbano. Para Villaça (1998), as via e os eixos são os fatores mais importantes que explicam a estruturação interna da cidade. 
Outra visão sobre o espaço interno da cidade é o trabalho de Marques (2003) destacando que a condição urbana contém, além das questões sociais e econômicas, as condições físicas, para que ela possa se sustentar. Os relevos constituem pisos sobre os quais se fixam as populações humanas e são desenvolvidas suas atividades, derivando, daí, valores econômicos e sociais que lhe são atribuídos.

Outro autor que ressalta a importância do estudo intraurbano é Costa (2008, p. 5), afirmando que, "à medida que vai ocorrendo o processo de urbanização, as cidades vão ganhando uma configuração espacial semelhante a outras de igual porte”. Suas argumentações sustentam que as modalidades urbanas tendem a se organizarem de forma semelhante, próxima, todavia, nunca idêntica, pois cada lugar é único.

Para estes autores, o estudo do espaço interno da cidade se direciona para uma compreensão específica, singular de cada lugar. A unicidade exige o exame interior, a fim de demonstrar sua estrutura e sua organização. Assim, o estudo do espaço interno da cidade tem relevância, no sentido de demonstrar a configuração atual da estrutura urbana analisada; todavia, Endlich (2011, p. 4) alerta para o fato de que, em relação às pequenas e médias cidades, "os territórios ou espaços intra urbanos destas localidades seguem como realidades ainda não contempladas adequadamente".

Autores como Gonçalves (2013, p. 27), ressaltam a importância da Geomorfologia para os estudos do espaço interno da cidade, pois é uma ciência do campo da Geografia Física que "faz interface com a Geografia Humana, uma vez que trabalha com questões sociais representadas em territórios e ocupações assentadas sobre o relevo". De acordo com esse autor, a Geomorfologia contribui para o estudo do relevo de diversas áreas do conhecimento, como planejamento urbano e regional, análise ambiental e áreas de risco.

Já Meneguett e Costa (2015), em sua abordagem acerca do espaço intraurbano, destacam a questão dos hiatos urbanos no contexto de Maringá/PR. Utilizam a metodologia da escola de morfologia inglesa, afirmam que, embora os fundamentos teóricos essenciais das faixas de hiato urbano conduzam para algum consenso, a investigação empírica em contextos culturais diversos apresenta muitos obstáculos práticos, assim como grandes oportunidades. Os autores consideram como hiatos urbanos os seguintes critérios:

Para a determinação das faixas de hiato urbano

- Lotes de grande área e usos variados, com baixa densidade.

- Grandes equipamentos institucionais. Não foram consideradas faixas de hiato urbano 
- Os equipamentos institucionais planejados e inseridos na área do Plano Inicial, exceto a zona industrial, por seu uso incongruente com o restante da malha.

- Áreas de reservas florestais, por se tratarem de áreas protegidas por lei que foram englobadas na malha urbana e que, portanto, são destituídas de decisão locacional. (MENEGUETTE; COSTA, 2015, p. 29).

Considerando-se o conjunto das obras pesquisadas, infere-se que, no Brasil, a reflexão teórica acerca da morfologia urbana é pouco desenvolvida, comparando-se ao volume de obras encontradas em relação aos temas cidade média e redes urbanas. Os autores consultados corroboram a premissa de que a temática do espaço interno da cidade e a morfologia urbana são temas complexos, que possuem uma gama de abordagens metodológicas e analíticas. De forma particular, ressalta-se a obra de Villaça (2001), uma das mais conhecidas e citadas.

No período atual, as pesquisas apresentam outros elementos investigativos, como a questão ambiental, na obra de Marques (2003), ou os hiatos urbanos, em Meneguette e Costa(2015). Pontuados aspectos importantes da morfologia, a próxima seção aborda os conceitos de sítio urbanos.

\section{Conceitos de sítio e tecido urbano}

Sítio e tecido são parâmetros da morfologia urbana com grandezas individuais; embora próximos e superpostos, são distintos; correspondem à porção natural e social da paisagem urbana. No âmbito do sítio urbano, configura-se e se estabelece o tecido urbano; de um modo geral, o sítio mantém-se, alterando-se a forma, já o tecido, ou desenho urbano, é, em certos casos, muito dinâmico.

Segundo Di Mauro (2012, p. 11): "no Brasil o estudo pioneiro sobre o sítio urbano é o trabalho de Ab’Saber (1957) na cidade de São Paulo/SP”. Nessa pesquisa, o conceito de sítio urbano trata da localização topográfica da construção da cidade, tendo como foco analítico a paisagem natural. Para Dollfus (1982), o sítio pode ser descrito, de maneira genérica, como lócus, ou o lugar que determinado objeto ocupa; logo, o sítio urbano pode ser entendido como o local de assentamento de uma cidade. De acordo esse autor, o tamanho e a posição são elementos fundamentais para o reconhecimento dessa categoria analítica.

George (1983) estabelece que o sítio é definido pelo quadro topográfico no qual se enraizou a cidade, pelo menos em suas origens. Mas ele pode mudar ou se deslocar, sempre em função da dinâmica do tecido urbano ao qual serve de suporte. O estudo de Almeida 
(2000) desenvolve uma investigação geossistêmica do sítio urbano de Feira de Santana/BA e destaca os conceitos da análise morfodinâmica, baseada em autores como Bertrand, Sotchava e Tricart. Segundo esse autor, os fundamentos metodológicos dessa abordagem têm como diretriz principal o enfoque sistêmico aplicado à observação integrada: "A compartimentarão do espaço em unidades geoambientais deve ser realizada com base nas ligações existentes entre os elementos fisionômicos, funcionais e antrópicos" (ALMEIDA, 2000, p. 10).

O sítio compreende a dinâmica social que o influencia, incorporando as relações sociais como fator relevante. Bettencourt (2007) destaca que, em consequência de sua evolução, hoje, “os sítios são uma síntese de vários momentos da história, com permanências, sem que, no entanto, ocorra um corte epistemológico com o passado" (BETTENCOURT, 2007, p. 25).

Araújo (2010) desenvolve uma avaliação do sítio urbano de Taboão da Serra/SP fundamentando-se na metodologia de aplicação de técnicas do geoprocessamento para a avaliação da superfície urbana. Para esse autor:

Sítio urbano se destaca por ser o campo onde as relações sociais se concretizam modificando as características físicas pré-existentes. Sítio remete à forma e sua base material, partindo de um problema dialético: propriedade geoecológicas versus propriedade sócio-reprodutoras. O sítio urbano é caracterizado na contemporaneidade, principalmente pelo estabelecimento da ação antrópica intensiva. (ARAÚJO, 2010, p. 51-52).

O conceito de sítio possui base epistêmica na Geomorfologia e em suas áreas afins, já que se refere, a princípio, à base natural do espaço urbano. A revisão de literatura empreendida indica que os estudos morfológicos urbanos sobre sítio feitos por autores da Geografia possuem intensa influência da geografia alemã e francesa. Destaca-se o pioneirismo de Ab'Saber (1958), sobre o sítio de São Paulo/SP.Autores como Dolffus (1982) e George (1983) afirmam que o sítio urbano é a base material na qual se assenta a cidade. Já Almeida (2000) e Araújo (2010) apontam para a interferência humana na dinâmica natural.

No âmbito do sítio urbano, configura-se e se estabelece o tecido urbano. O desenho urbano ou tecido possui importância fundamental para a compreensão da conformação e da estruturação do espaço urbano. Um dos pioneiros da investigação sobre tecido urbano é Amorim Filho (1978; 2005), que desenvolveu um modelo morfológico específico para cidades médias.

Além desse autor, Del Rio (1990) afirma que as primeiras pesquisas sobre tecido se fortaleceram na Geografia a partir dos questionamentos sobre as atitudes modernistas em 
relação às cidades históricas e sobre as relações sociais que as regem. Para ele, na compreensão do fenômeno urbano, é fundamental "estudar o tecido urbano e seus elementos construídos formadores de sua evolução, transformações, inter- relações e os processos sociais que os geraram" (DEL RIO, 1990, p. 71).

Para autores como Costa (2008), o que chama a atenção no desenho de uma cidade é a sua tessitura, a trama dos seus elementos. Segundo esse pesquisador, o tecido urbano é configurado pelo sistema viário, pelo padrão do parcelamento do solo, pela aglomeração e pelo isolamento das edificações, assim como pelos espaços livres.

Em pesquisa mais recente sobre a cidade de São Luiz/MA, Oliveira et al. (2010, p. 4) retomam a abordagem de Lefebvre sobre a importância da análise interna da cidade, destacando que "o tecido urbano, não designa, de maneira restrita, o domínio edificado nas cidades, mas o conjunto das manifestações do predomínio da cidade sobre o campo". Nessa acepção, uma segunda residência, uma rodovia, um supermercado em pleno campo fazem parte do tecido urbano, mais ou menos denso, mais ou menos espesso e ativo.

Dessa forma, o tecido urbano pode ser compreendido tanto do ponto de vista estrutural, tendo como base a conformação da cidade, quanto do ponto de vista processual, quer dizer, pelo jogo de relações entre seus diferentes atores, em especial o Estado e o capital privado. Nessa abordagem, julga-se relevante compreender a organização do tecido urbano, a fim de buscar inferências sobre seu processo de formação, que possui três grandes significados:

Primeiro, o tecido urbano tem uma utilidade prática básica ao prover orientação: nosso mapa mental e, portanto, a eficiência com que funcionamos espacialmente, depende do nosso reconhecimento dos locais. Segundo, tem valor intelectual ao ajudar tanto o indivíduo quanto a sociedade a se orientar no tempo: uma imagem da cidade, especialmente a de uma cidade bem estabelecida, apresenta uma forte experiência visual da história de uma região, ajudando o indivíduo a se situar em uma maior amplitude da sociedade em transformação, estimulando a comparação histórica e assim fornecendo uma base mais informada para a tomada de decisões. Terceiro, possui valor estético: por exemplo, no impacto visual e no sentido de orientação instituídos por elementos dominantes como igrejas ou castelos, e no estímulo à imaginação alimentado por variações na largura e na direção das ruas. Estes três atributos estão inter-relacionados e as experiências estéticas e emocionais estão forte e particularmente entrelaçadas - ainda que não necessariamente de modo dependente - com a apreciação do significado histórico e geográfico do tecido urbano (REGO; MENEGUETTI, 2011, p. 125).

Os autores destacam a funcionalidade desse parâmetro analítico em três abordagens: orientação, intelecto e estético - todos são complementares e se correlacionam na 
conformação da cidade. Devido à sua multidimensionalidade, é campo fértil para o entendimento da evolução socioespacial. Considerando-se as abordagens nacionais relacionadas ao tecido, destacam-se as pesquisas de Amorim Filho (2005), que propôs um modelo, de Del Rio (1999) e de Costa (2008), que enfatizam elementos como as vias, as construções e os espaços vazios.

Todos os autores consultados reafirmam que sítio e tecido são elementos fundamentais para a compreensão do espaço interno da cidade. Pontuados esses conceitos, a seção a seguir apresenta a delimitação do espaço urbano de Janaúba/MG.

\section{Perímetro urbano de Janaúba/MG}

A identificação e a compreensão do sítio e do tecido urbano dependem da delimitação do perímetro urbano no município de Janaúba/MG. Essa definição é dada em nível teórico, ou seja, na definição do que é a cidade, sendo também definida em nível prático, na realidade de cada cidade. Atualmente, o perímetro urbano é expresso essencialmente nos Planos Diretores Municipais. As definições (teóricas e práticas) são, em alguns casos, distintas e até mesmo distantes. Neste estudo, apresenta-se a definição municipal do espaço urbano de Janaúba/MG.

O Plano Diretor Municipal de Janaúba (PMDJ, 2007) foi o primeiro documento a tratar a caracterização da área urbana local de forma mais precisa. No entanto, não foram empregados os termos específicos das ciências espaciais, como sítio e tecido, e nem houve um posicionamento teórico conceitual acerca do que seja a área urbana. $\mathrm{O}$ documento apresenta uma aproximação figurativa do que se denomina perímetro urbano. As imagens apresentadas não possuem os elementos básicos da cartografia, como escala, pontos referenciais, legenda e outros.

A definição do perímetro urbano derivou da Lei $10.257 / 2001$, que promove a divisão do município em zonas rurais e urbanas, de forma a auxiliar o direcionamento das políticas públicas. Neste, a propriedade urbana cumpre sua função quando atende às exigências fundamentais de ordenação da cidade expressas no Plano Diretor. A figura um mostra o perímetro urbano e a área urbanizada do PDMJ (2007) de Janaúba/MG. 
Figura 1 - Representação da delimitação do perímetro urbano de Janaúba/MG

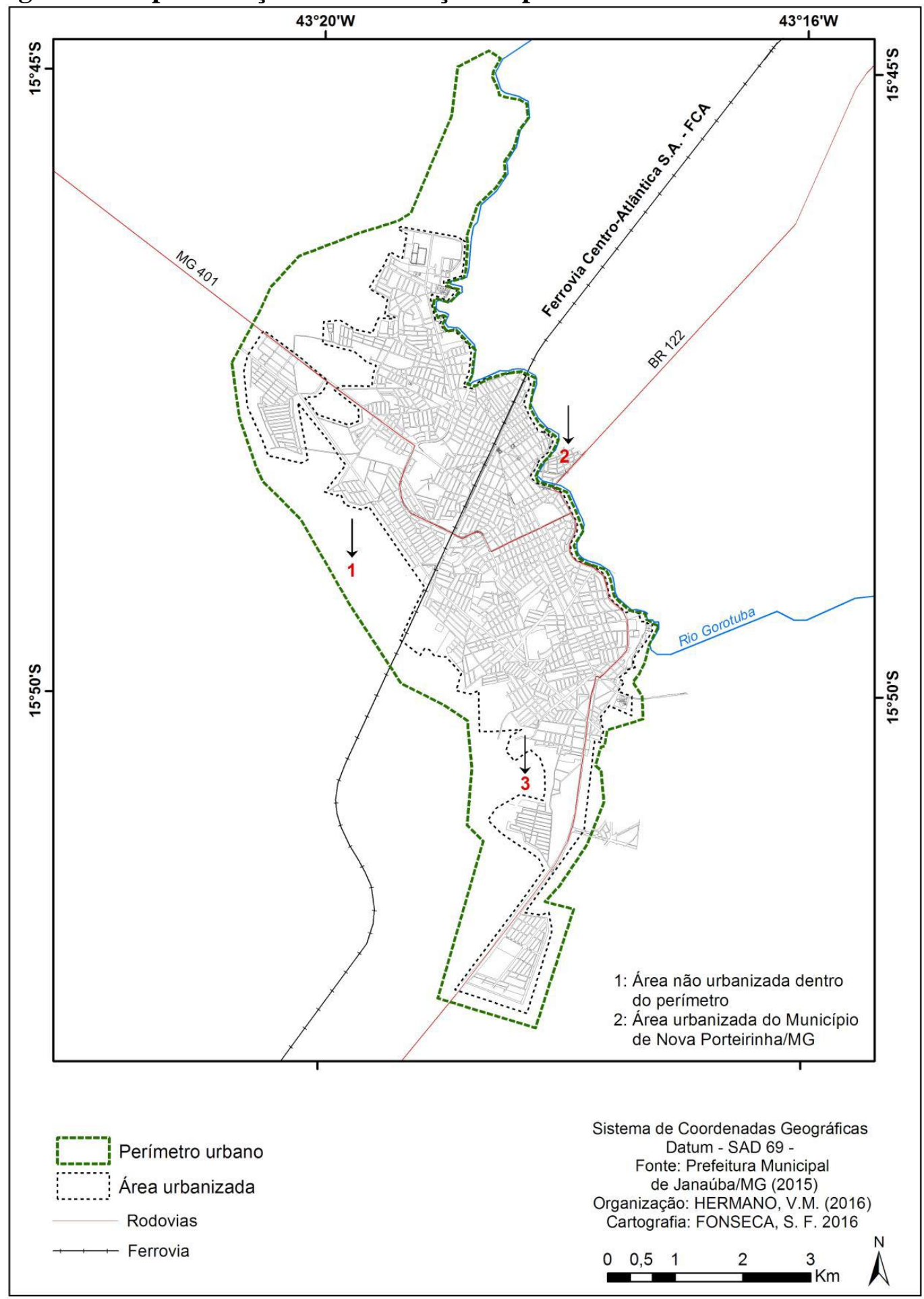

Fonte: Prefeitura Municipal de Janaúba, 2015. Organização: Fonseca e Hermano (2016).

$\mathrm{Na}$ figura um, a linha verde é a delimitação do perímetro urbano, e a linha pontilhada, sua área urbanizada. Nota-se que, no período considerado, a área urbanizada se distribui em sentido paralelo à rede principal de drenagem, com predominância direcional 
Norte/Sul. Os pontos um e três retratam uma área não urbanizada dentro do perímetro urbano. O ponto dois se refere à área urbana do município de Nova Porteirinha/MG, e, portanto, não pertence ao território do município de Janaúba/MG, embora tenha sido representada, devido à sua proximidade.

Essa representação, elaborada a partir do PDMJ (2007), não parece ser pautada em postulados técnicos ou científicos, e indica a avaliação da administração pública municipal acerca do espaço urbano de Janaúba/MG. É uma leitura pública e administrativa que retrata, em grande parte, a real e atual estrutura urbana da cidade. O PDMJ (2007) pontua o zoneamento e a delimitação do espaço urbano da seguinte forma:

Parágrafo Único: O zoneamento ora regulado, não derroga, ab-roga ou revoga o zoneamento geográfico da sede do município em vigor, que o delimita em:

I. Zona Central: compreende os bairros Centro, Novo Paraíso, Gameleira, Boa Esperança e Padre Eustáquio;

II. Zona Norte: compreende os bairros Veredas, Rio Novo, Barbosas e Santa Terezinha;

III. Zona Sul: compreende os bairros Santa Cruz, Santo Antônio, São Gonçalo, Saudade e Esplanada;

IV. Zona Oeste: compreende os bairros Dente Grande, Planalto e Ribeirão do Ouro;

V. Zona Sudoeste: compreende os bairros Cohab, Isaías Pereira, Algodões e São Vicente;

VI. Zona Noroeste: compreende os bairros Cerâmica, Boa Vista e São Lucas. (JANAUBA, 2007, p.9).

No documento, a área urbana é definida em zonas, tendo como ponto de partida o centro histórico da cidade, denominado de zona central. A metodologia dessa classificação não é descriminada no documento (a figura dois mostra esse zoneamento).

Observa-se que, na figura, a área urbana de Nova Porteirinha/MG está fora da representação, e as seis zonas foram definidas segundo a localização geográfica, com exceção da zona central, definida conforme a funcionalidade. A análise indicou que, para a administração pública local, ora a zona urbana de Nova Porteirinha/MG é reconhecida, ora não é.

Em 2015, a administração pública local, gestão 2012-2016, alterou a delimitação jurídica do espaço urbano do município, promovendo uma expansão do perímetro urbano, por meio da Lei Municipal 2.104, de março de 2015. No entanto, no PDMJ (2015), não consta nenhuma representação cartográfica, sendo ainda bem menos detalhado que o documento de 2007. Aproxima-se de uma simples atualização legislativa. No documento, a delimitação do perímetro urbano fica da seguinte forma: 
Figura 2 - Representação do zoneamento da cidade de Janaúba/MG

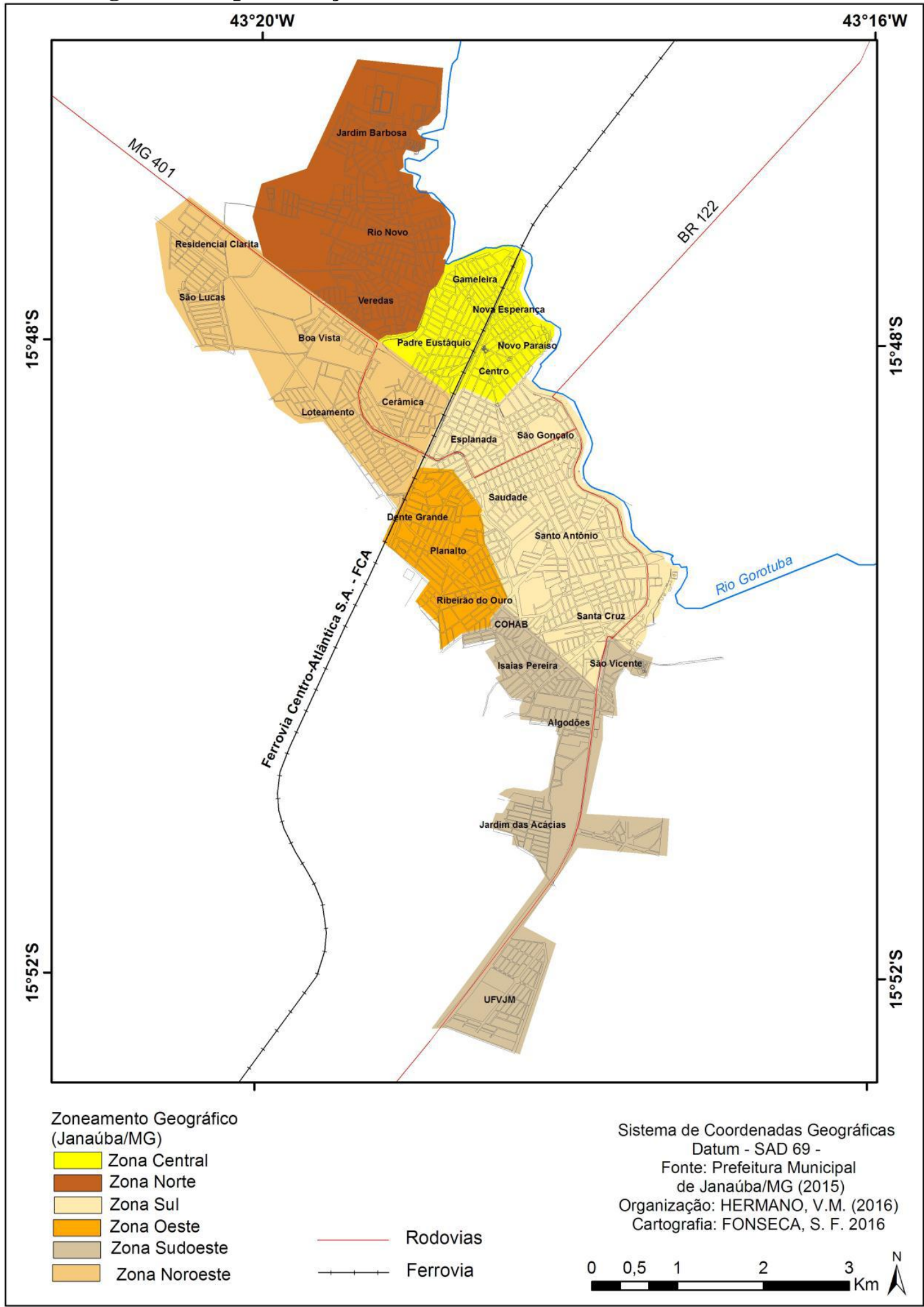

Fonte: Prefeitura Municipal de Janaúba, 2015. Organização: Fonseca e Hermano (2016).

1.Zona Central: compreende o centro;

11.Zona Leste: compreende os bairros Novo Paraíso e Nova Esperança; 
11l.Zona Centro-norte: compreende os bairros Padre Eustáquio, Gameleira e Veredas;

IV.Zona Centro-sul: compreende os bairros Esplanada, Saudade e São Gonçalo;

V.Zona sul: compreende os bairros Santo Antônio e Santa Cruz;

Vl.Zona sudeste: compreende os bairros São Vicente, Canafístula, Bico da Pedra e Cidade Universitária;

Vll.Zona oeste: compreende os bairros Cerâmica, Dente Grande, Planalto e Pedra Preta;

Vll.Zona sudeste: compreende os bairros Ribeirão do Ouro, Cohab, Isaías Pereira, Baixa da Colônia, Algodões e Algodões 2;

1X.Zona noroeste: compreende os bairros Boa Vista, Parque Industrial Clarita, Residencial Clarita, São Lucas e Caraíbas;

X.Zona norte: compreende os bairros Rio Novo, Barbosas, Santa Terezinha, Piranhas e Jacarezinho;

Xl.Região Sudeste: compreende o Balneário Bico da Pedra e o entorno do Lago Bico da Pedra (JANAUBA, 2015, p.6).

O zoneamento da área urbana, em 2015, expande o número de zonas: se, no PDMJ (2007), eram seis zonas, no PDMJ (2015), são onze. Além de ter aumentado o número de zonas urbanas, novos bairros foram incluídos, como Cidade Universitária e Cohab, localizados na área Sul da figura dois. Essa inclusão reflete a expansão urbana, em especial na direção Sul. A zona Sudeste se refere à região do Lago Bico da Pedra, local que não pode ser considerado como área da cidade, do ponto de vista legal, pois não exerce nenhuma função típica dessa modalidade, como residencial, comercial ou industrial. Nessa área existem apenas casas de veraneio supervalorizadas. A figura três mostra parte dessa zona.

Essa zona deveria ser de preservação permanente, conforme a Legislação Ambiental Brasileira, afinal, localiza-se próxima ao lago Bico da Pedra. Tal questão local já foi amplamente discutida na pauta legislativa da cidade e é alvo de várias polêmicas. Representa a divergência de duas classes sociais: daqueles que são a favor da urbanização, devido à valoração dos imóveis, e dos que são contra, em função de sua localização na área de preservação. O fato é que o PDMJ (2015) o reconhece como área urbana.

Ao se analisar os Planos Diretores Municipais de 2007 e de 2015, nota-se que a definição de perímetro urbano adotada pelo poder público municipal não está diretamente ligada à função que determinada área exerce, nem mesmo está vinculada a algum conceito teórico. A delimitação urbana local é influenciada pelos parâmetros políticos que, por vezes, fogem ao escopo científico. Tal verificação indica que não há, até o momento, uma produção técnica ou científica que delimite de forma exata e detalhada o que seja realmente o espaço urbano de Janaúba/MG. 
Figura 3 - Foto da área Bico da Pedra, situada na zona Sudeste da cidade de Janaúba/MG

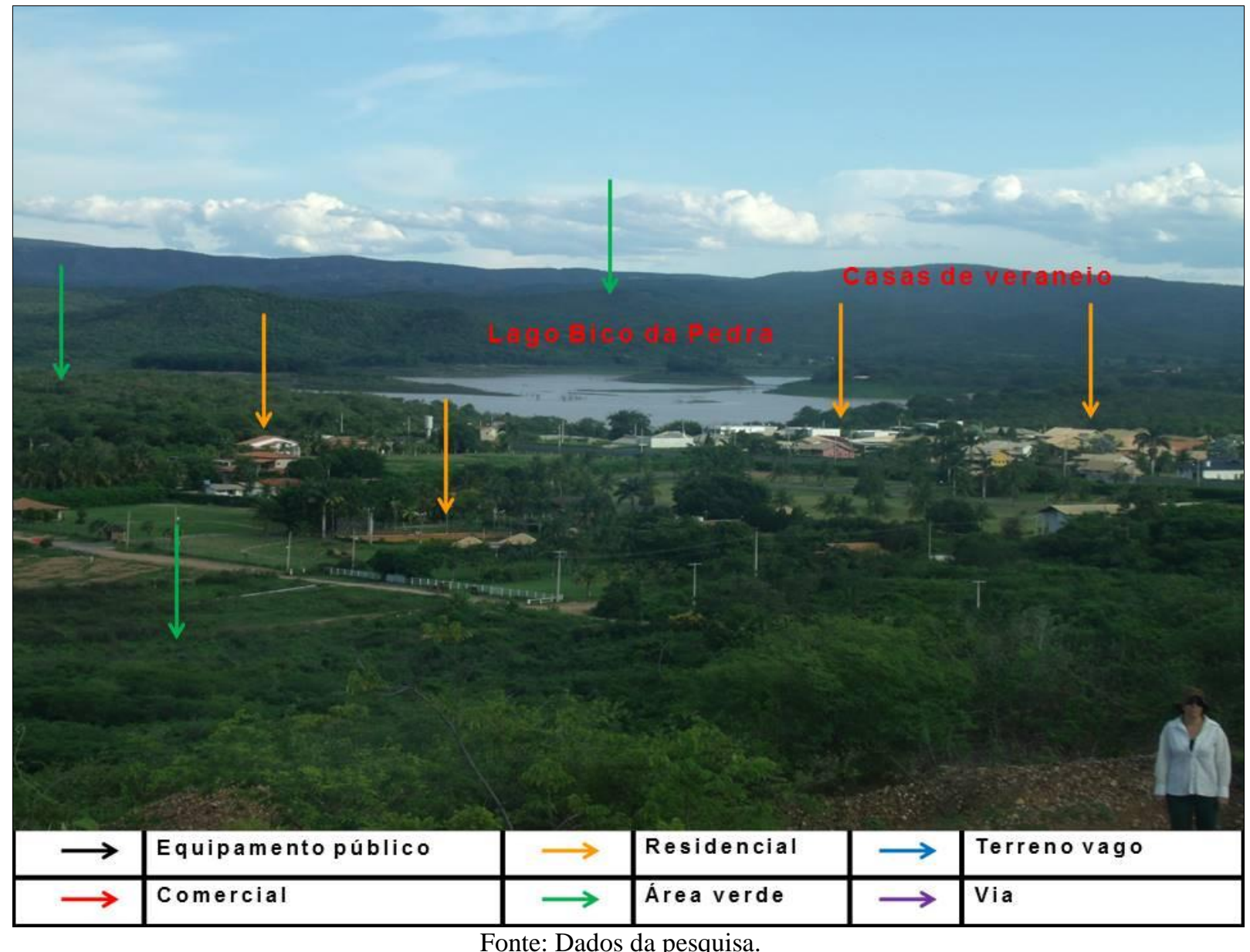

As condições específicas encontradas retratam um processo de urbanização/ocupação que ocorre parcialmente à revelia do poder público e das delimitações técnicas. Portanto, nesta pesquisa, será considerado como espaço urbano do município de Janaúba/MG o perímetro urbano delimitado pelo relatório da PDMJ (2015), com exceção da zona Sudeste, porque essa não exerce função urbana. Assim, considera-se que o sítio urbano da cidade, que tem como marco espacial o perímetro urbano definido pelo PDMJ (2015), está totalmente inserido na bacia hidrográfica do Rio Gorutuba, em sua margem esquerda. O sítio da cidade será contemplado no tópico que se segue.

\section{Sítio da cidade de Janaúba/MG}

A identificação do sítio urbano está pautada na abordagem sistêmica, que é ampla e complexa; mas, nesta pesquisa, optou-se por considerar os seguintes elementos: o clima, a 
geomorfologia, o sistema hídrico e a vegetação, bem como a interação entre eles. Do ponto de vista climático, ressaltam-se as altas temperaturas e os ciclos chuvosos irregulares. Hermano (2013), em estudo específico sobre a oscilação do período chuvoso de Janaúba/MG, alertou para seu caráter pluviométrico extemporâneo, e também para os momentos de baixo índice pluviométrico. O gráfico dois mostra a variação no município.

\section{Gráfico 2 - Índice pluviométrico do município de Janaúba/MG, de 1992 a 2015}

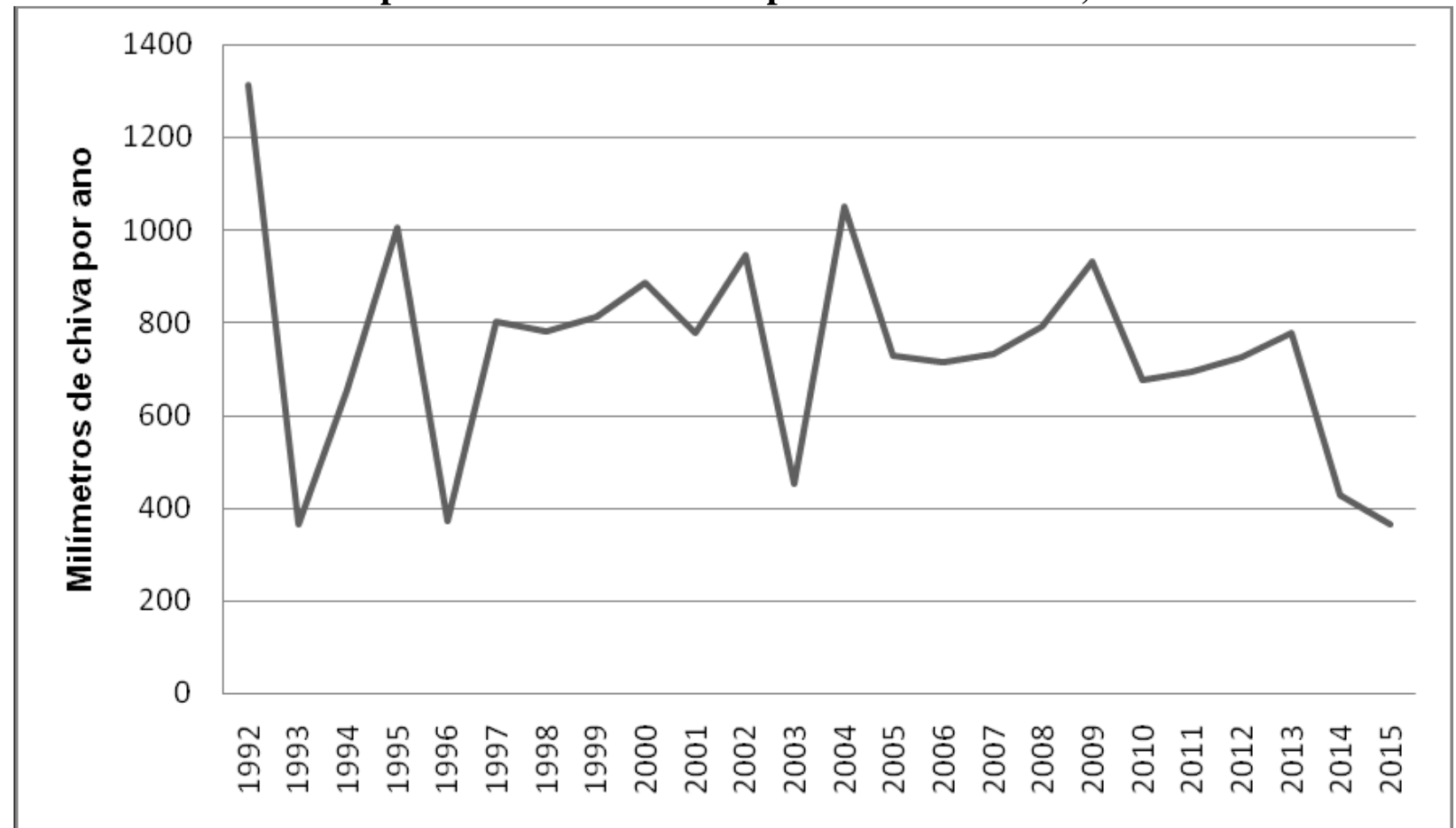

Fonte: INMET, 2016.

No gráfico dois, pode-se identificar a oscilação das chuvas na localidade em análise. Evidencia-se que os anos de melhores índices foram 1992, 1995, 2004, 2009; e os anos críticos, 1993,1995, 2003, 2015 e 2016. Esse padrão indica um ciclo climático do tipo semiúmido. Os dados expõem a realidade de um quadro em que a deficiência hídrica é uma realidade a ser enfrentada, interferindo no processo de ocupação do território urbano.

Geomorfologicamente, nota-se a predominância da superfície aplainada, de base geológica sedimentar, compondo uma planície fluvial que possui gradientes altimétricos suaves. O perfil topográfico Norte-Sul da cidade de Janaúba/MG, exposto na figura quatro, destaca essa suavidade, que também se verifica na direção Leste-Oeste. $O$ gradiente altimétrico é de apenas 12 metros, no primeiro caso. 
Figura 4 - Perfil topográfico Leste-Oeste de Janaúba/MG

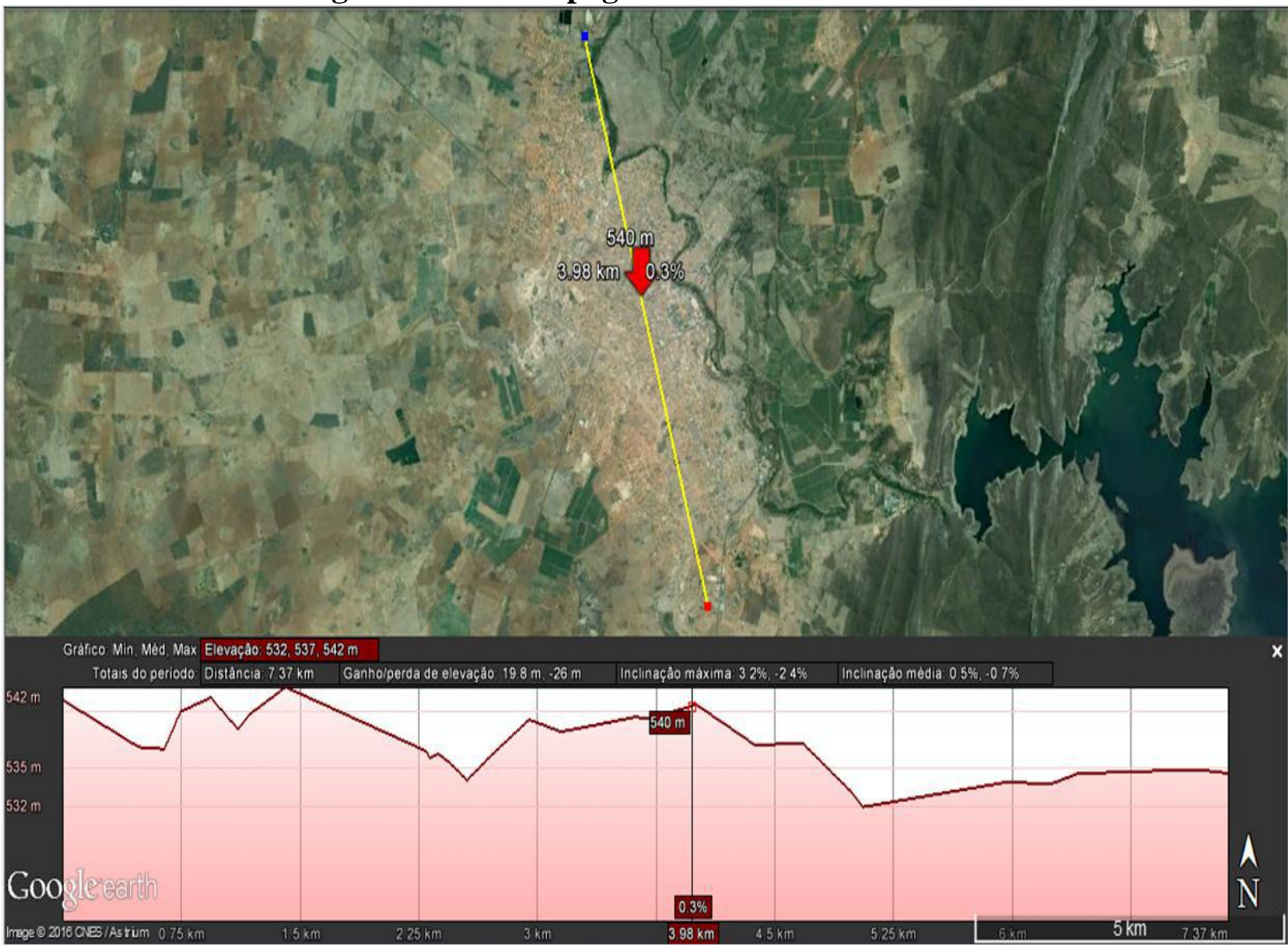

Fonte: Google Heart (2016).

O transecto evidencia a suavidade do relevo no sítio urbano de Janaúba/MG. No contexto de seu relevo, aliado às características climáticas, o sistema hídrico do sítio de Janaúba/MG é composto pelo rio Gorutuba e por suas lagoas intermitentes, a exemplo dos pontos um e dois da figura cinco. A formação de lagoas é uma característica comum nas cidades ribeirinhas do rio São Francisco, na região Norte de Minas, verificada também na pesquisa de Silveira e Oliveira (2014).

A intermitência é uma característica típica do regime pluviométrico local, tanto no rio como em suas áreas contribuintes. Essa sazonalidade confere às lagoas urbanas um aspecto relevante para a compreensão do sítio urbano, já que ficam secas a maior parte do ano, visíveis, muitas vezes, apenas no período chuvoso. Duas das lagoas urbanas de Janaúba/MG, pontos um e dois da figura cinco, são denominadas popularmente de "Lagoa do Ribeirão do Ouro" e de "Buraco de Amélia" (esta última pode ser visualizada na figura seis). 
Figura 5 - Representação do sistema hídrico no perímetro urbano de Janaúba/MG

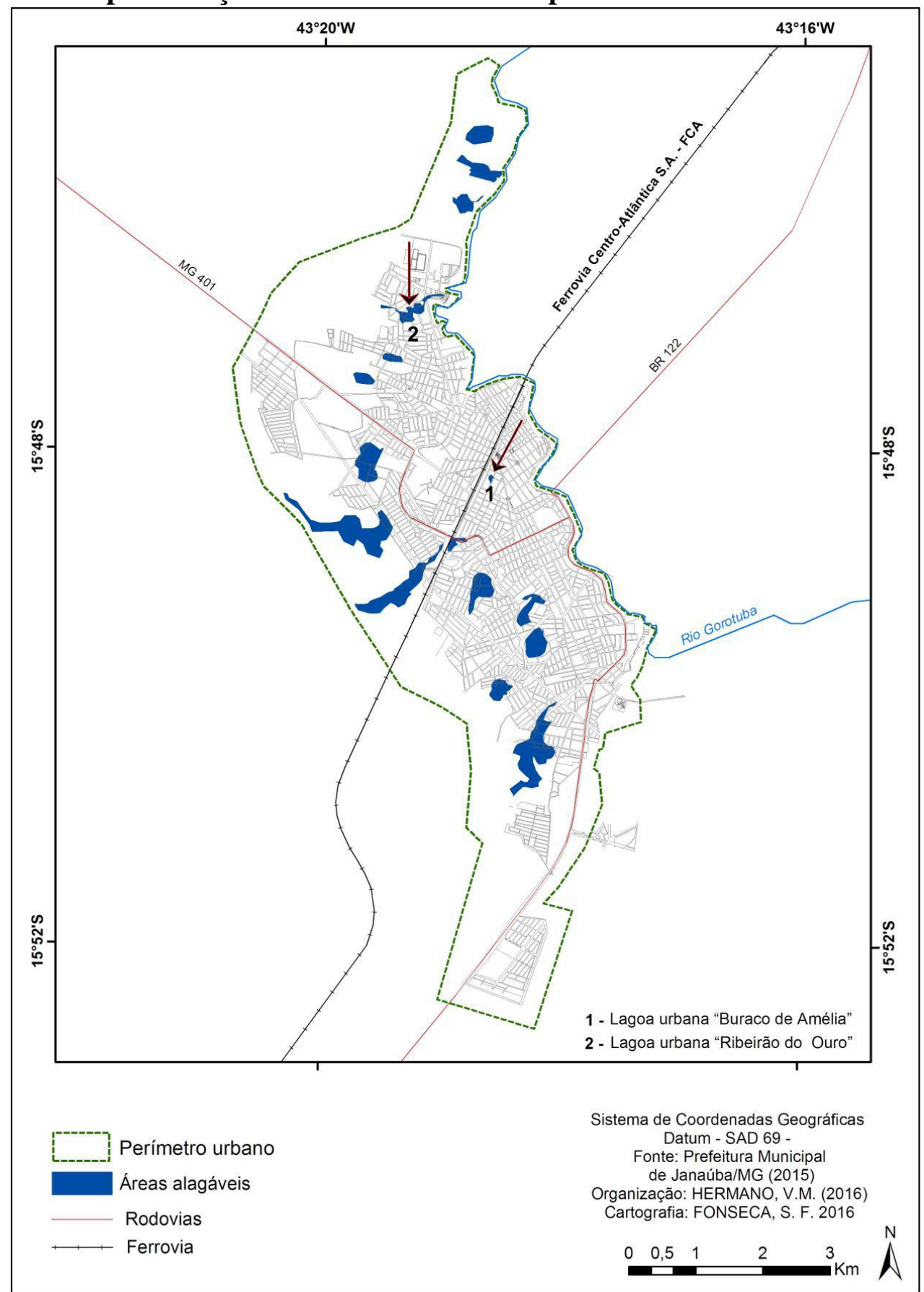

Fonte: Prefeitura Municipal de Janaúba, 2015. Organização: Fonseca e Hermano (2016).

A figura seis demonstra o processo de ocupação urbana no entorno da lagoa. A vegetação típica é a transição entre cerrado e caatinga, e pode ser descrita de forma preliminar em dois grandes grupos: as de fundo de vale ou de mata ciliar e a antiga vegetação dos níveis adjacentes. Souza Junior (2002) afirma que a vegetação da mata ciliar do Gorutuba é marcada 
por plantas que sofrem forte influência da vegetação circunvizinha, adaptadas a ambientes mais úmidos, com características de cerrado e de caatinga.

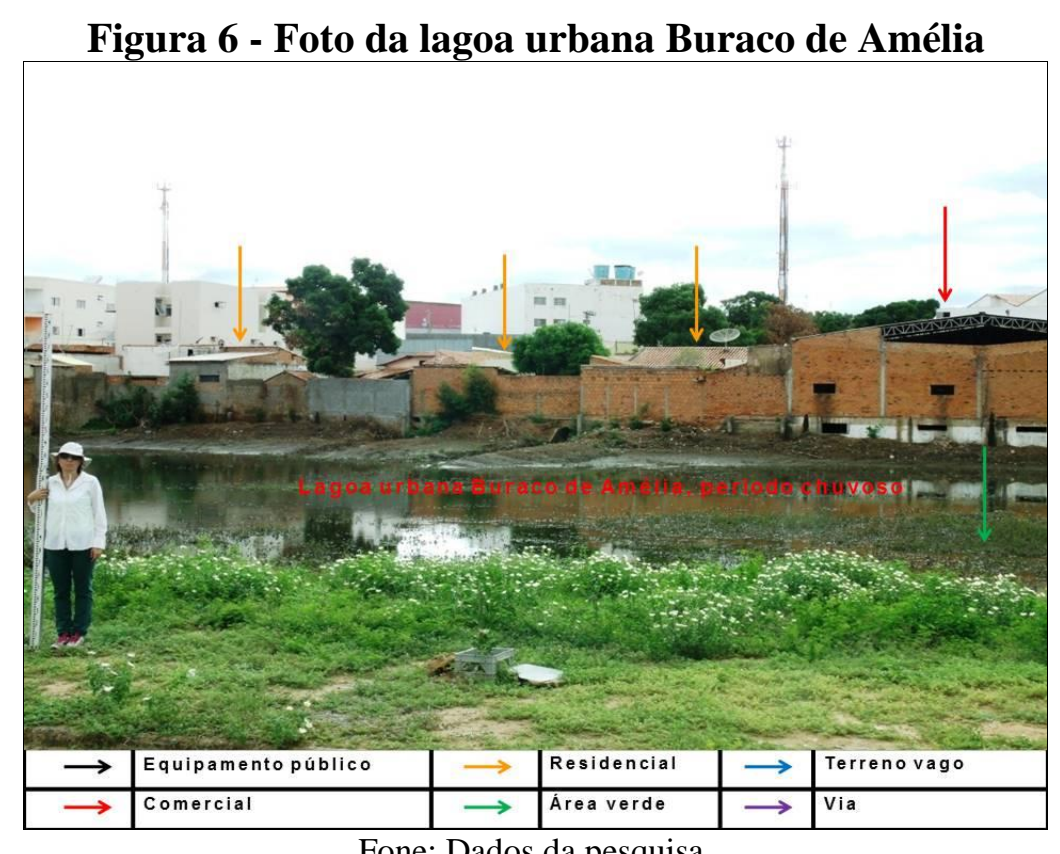

Fone: Dados da pesquisa.

No que refere às áreas adjacentes, profundamente alteradas pelo processo de urbanização, existem algumas amostras pontuais em áreas remanescentes. A pesquisa de Santos e Hermano (2015) indicou a presença de uma vegetação típica de caatinga, sendo a espécie mais comum a Albisia Rascerelle, popularmente conhecida como Angico Branco ou Farinha Seca (figura sete).

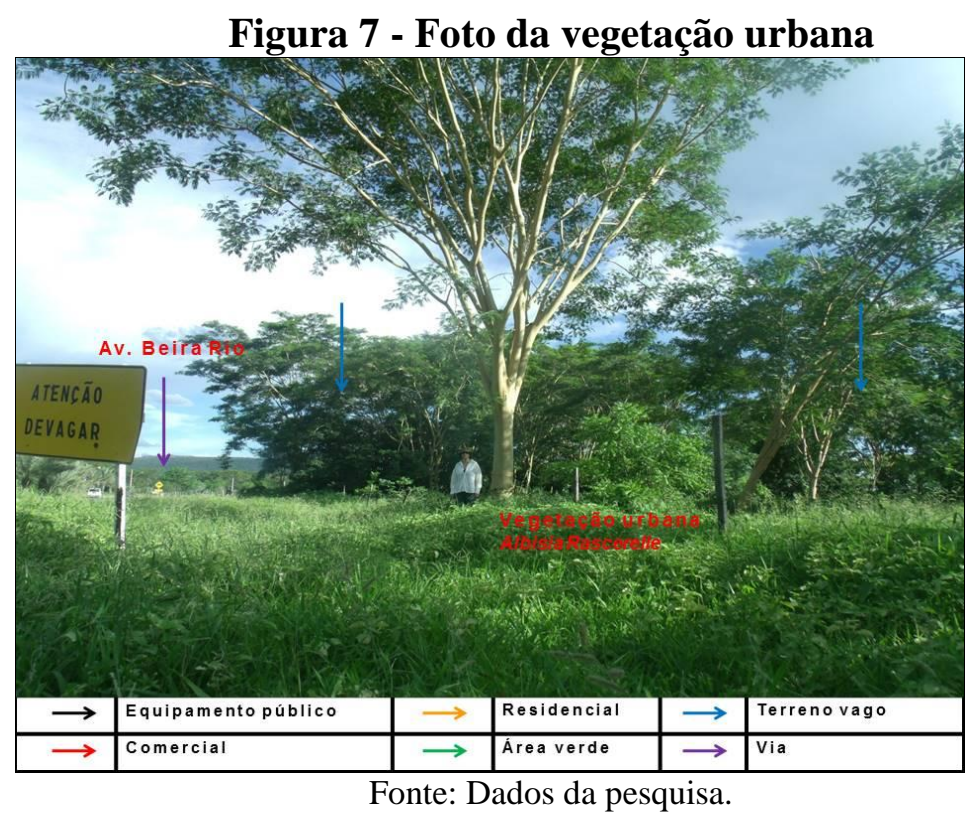


O quadro natural da cidade aproxima-se das características ambientais do município, ou seja, o espaço municipal (mais amplo) e o espaço urbano (restrito) são similares. A partir da abordagem sistêmica, que leva em consideração um conjunto de aspectos da paisagem do sítio urbano de Janaúba/MG, é possível afirmar que alguns fatores puderam influenciar positivamente o processo de urbanização, como o relevo essencialmente plano, a proximidade do rio Gorutuba e a presença da Barragem Bico da Pedra, ratificando o sistema hídrico como agente relevante da formação da estrutura da cidade. Por outro lado, a ocupação urbana em áreas de preservação permanente, como as lagoas intermitentes e o contorno da barragem, prova que esse sítio e suas características geossistêmicas estão sendo desprezados pelo processo de ocupação urbana.

Esse tipo de resultado também é verificado por Almeida (2010); em seu estudo sobre o sítio urbano de Feira de Santana/BA, afirma que a abordagem sistêmica aplicada à análise da paisagem permitiu demonstrar as interrelações existentes entre o fator antrópico e o meio natural, bem como evidenciar a forte predominância do papel do sistema hidrológico na dinâmica atual.

\section{Tecido urbano de Janaúba/MG}

Nesta pesquisa, o tecido de cidade é dado pelas edificações, pelas ruas, pelas quadras e pelos lotes, pelos parques, pelas praças, pelos monumentos nos seus mais variados arranjos e pelos espaços vazios. Esses componentes são considerados como organismos constantemente em atividade e, assim, em transformação ao longo do tempo. A figura oito destaca as áreas vazias do tecido urbano de Janaúba/MG.

O cartograma expõe a distribuição das áreas urbanizadas e das consideradas vazias. Esse tecido apresenta certa continuidade ao longo dos principais eixos viários, e também certa descontinuidade, nas áreas periféricas; seu sentido preferencial é o Norte-Sul, acompanhado a drenagem do rio Gorutuba. Os espaços vazios ocorrem por diversos motivos. Segundo a pesquisa, um desses fatores deve-se à característica de seu sítio, com a formação de lagoas, como é o caso do ponto um, indicado na figura seis.

Levando-se em conta as condições históricas do local e da região, indicados no trabalho de Hermano (2016), juntamente à forma da estrutura urbana representada na figura, percebe-se que a expansão do tecido urbano sobre o perímetro acompanhou a dinâmica histórica. O tecido urbano de Janaúba/MG evoluiu em função dos equipamentos públicos, em 
especial pela instalação da Ferrovia, da Barragem Bico da Pedra e do projeto de Irrigação, além das rodovias. A figura nove mostra a evolução do tecido urbano de Janaúba/MG.

\section{Figura 8 - Representação dos vazios urbanos de Janaúba/MG}

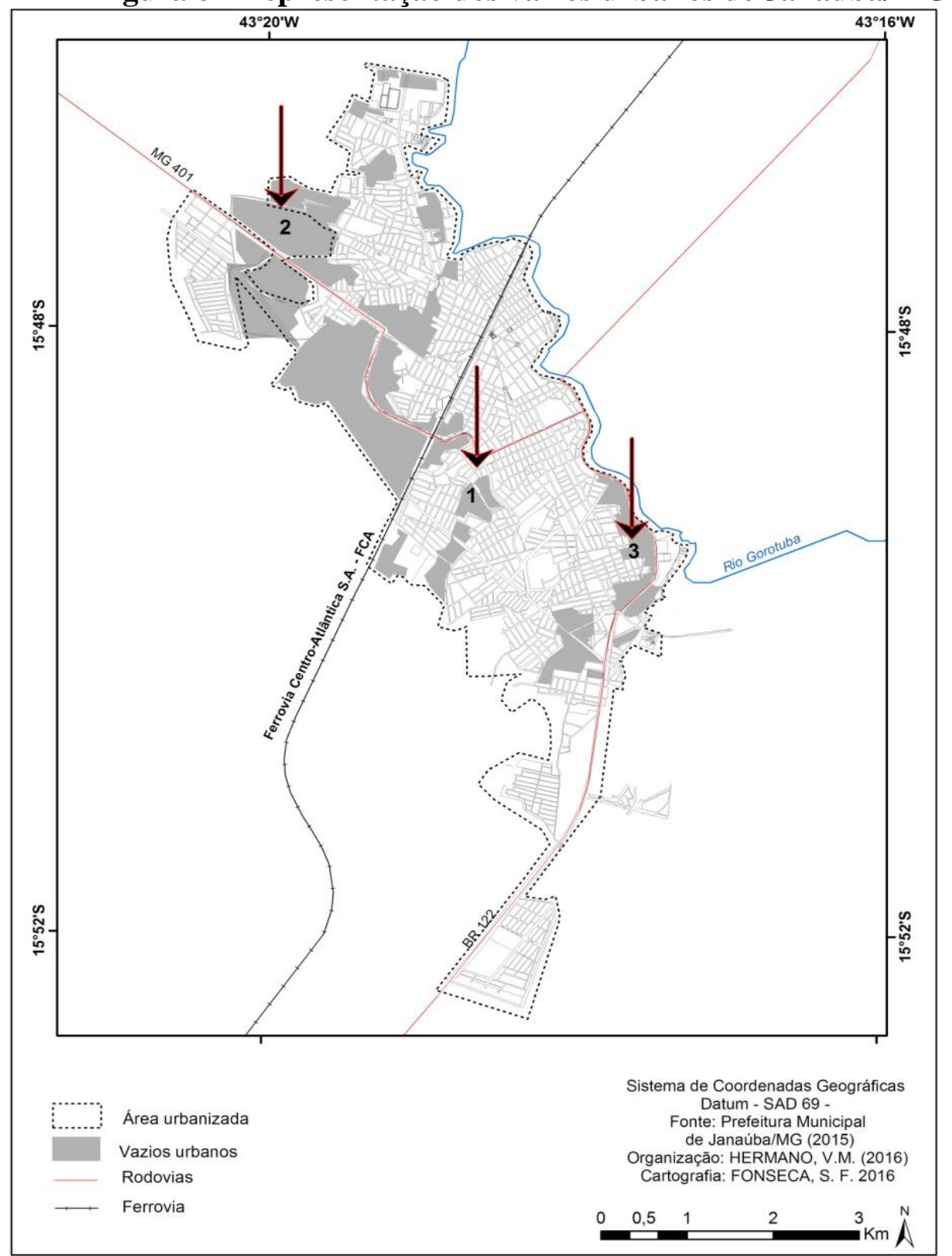

Fonte: Prefeitura Municipal de Janaúba, 2015. Organização: Fonseca e Hermano (2016).

A expansão do tecido urbano de Janaúba/MG foi direcionada pela sequência de implementação das principais vias. Na primeira etapa, antes de 1934, era um pequeno povoado; na segunda, depois de 1934, com a ferrovia, ocorreu a criação do município e a formação inicial da cidade. A terceira etapa, em 1979, corresponde ao período da instalação dos projetos de irrigação e das avenidas que ligam as rodovias estaduais. Atualmente, com as 
direções principais de expansão do tecido urbano nas direções Sul e Norte, seguindo a orientação das Brs (HERMANO, 2016).

A análise do quadro evolutivo do tecido urbano de Janaúba/MG comprova que a expansão do tecido urbano ocorre a partir da organização da estrutura viária. Resultados similares foram apreciados por Villaça (2001), afirmando que o crescimento urbano é altamente influenciado pelas vias (rodovias e ferrovias-regionais), ou seja, as vias e os eixos de expansão são os principais fatores de organização interna. É nítido o fato de a dinâmica do crescimento da cidade estar atrelada aos eixos viários de ligação a grandes centros urbanos do Sul, do Sudeste e do Nordeste.

Figura 9 - Evolução do tecido urbano

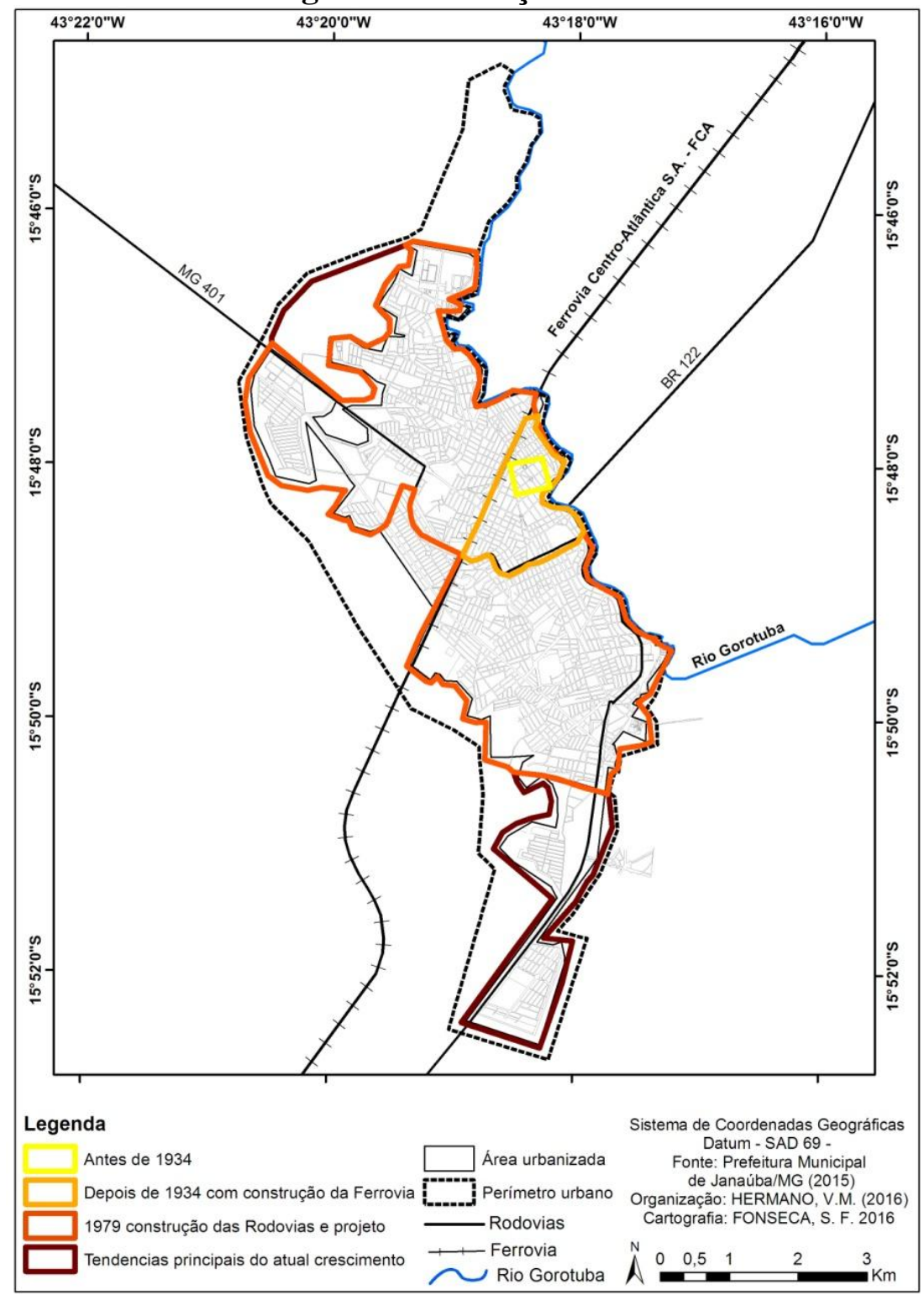

Fonte: Prefeitura Municipal de Janaúba, 2015. Organização: Fonseca e Hermano (2016). 
Na compreensão da estrutura atual da cidade, aplica-se o modelo morfológico de Amorim Filho (2005). A analogia entre os atributos do zoneamento morfológico das cidades médias e os de Janaúba/MG é exibida no quadro dois.

\section{Quadro 2 - Estudo comparativo entre o modelo morfológico e a estrutura urbana de Janaúba/MG}

\begin{tabular}{|c|c|c|}
\hline Zona & Atributos, segundo Amorim Filho & Janaúba/MG \\
\hline Central & $\begin{array}{l}\text { Centro principal, bem-definido funcionalmente (forte presença } \\
\text { de equipamentos "raros", de alcance regional). Diferenciação } \\
\text { funcional interna com paisagem e morfologia típicas } \\
\text { (construções em altura; forte movimento de veículos e de } \\
\text { pessoas; animação). Função residencial superada pelas funções } \\
\text { terciárias; centro com polarização, pelo menos microrregional, } \\
\text { podendo alcançar o nível regional de polarização. }\end{array}$ & $\begin{array}{l}\text { Linear: } \\
\text { Avenida do Comércio e avenida } \\
\text { Maurício Augusto de } \\
\text { Azevedo;rua Francisco Sá. }\end{array}$ \\
\hline Pericentral & $\begin{array}{l}\text { Extensa espacialmente; função residencial predominante e } \\
\text { presença de vilas especializados ou polifuncionais (estas } \\
\text { últimas, pequenas) ao longo dos eixos de praças e de } \\
\text { entroncamentos. } \\
\text { Diferenciação morfológica e paisagística em função de } \\
\text { diferenças socioeconômicas, com presença de equipamentos } \\
\text { especiais, como hospitais, universidades, estações rodoviárias e } \\
\text { ferroviárias etc. }\end{array}$ & $\begin{array}{l}\text { Linear: } \\
\text { Av. Manuel Athaíde, parte da } \\
\text { avenida Brasil } \\
\text { Área: } \\
\text { Bairros: Centro, região do } \\
\text { Hospital Regional }\end{array}$ \\
\hline Periférica & $\begin{array}{l}\text { De dois tipos: contínua (como prolongamento da zona } \\
\text { pericentral) e descontínua, ou polinuclear, formada por } \\
\text { loteamentos (unidades organizadas) ou "vilas" (desorganizadas } \\
\text { e, em certas regiões, verdadeiras favelas). Presença de } \\
\text { subcentros polifuncionais bem modestos (comércio e serviços } \\
\text { de vizinhança) e de alguns subcentros especializados. Extensão } \\
\text { proporcional ao nível hierárquico e ao tamanho da cidade }\end{array}$ & 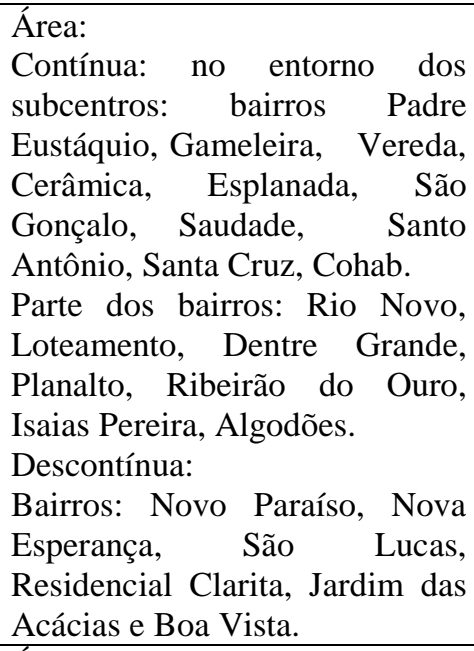 \\
\hline Periurbana & $\begin{array}{l}\text { Presença de uma zona de transição urbano-rural mais ou menos } \\
\text { extensa e que se confunde, nas imediações da cidade, com a } \\
\text { periferia polinuclear e descontínua. } \\
\text { Presença de alguns equipamentos terciários pontuais. Aumento } \\
\text { das casas de campo, de clubes campestres e de hotéis-fazenda; } \\
\text { diminuição das fazendas e aumento das pequenas propriedades, } \\
\text { com produtos para a cidade média. }\end{array}$ & $\begin{array}{l}\text { Área: } \\
\text { Bairros: Jardim Barbosa, } \\
\text { Universitário, São Vicente } \\
\text { Parte dos bairros: Rio Novo, } \\
\text { Loteamento, Dentre Grande, } \\
\text { Planalto, Ribeirão do Ouro, } \\
\text { Isaias Pereira e Algodões. }\end{array}$ \\
\hline
\end{tabular}

Fonte: Amorim Filho (2005) e dados da pesquisa. 
Esse esquema demonstra a aplicação do modelo de Amorim Filho (2005) à cidade de Janaúba/MG. A classificação permitiu a elaboração de um mapeamento, que é apresentado na figura dez.

\section{Figura 10 - Zoneamento morfológico funcional da cidade de Janaúba/MG}

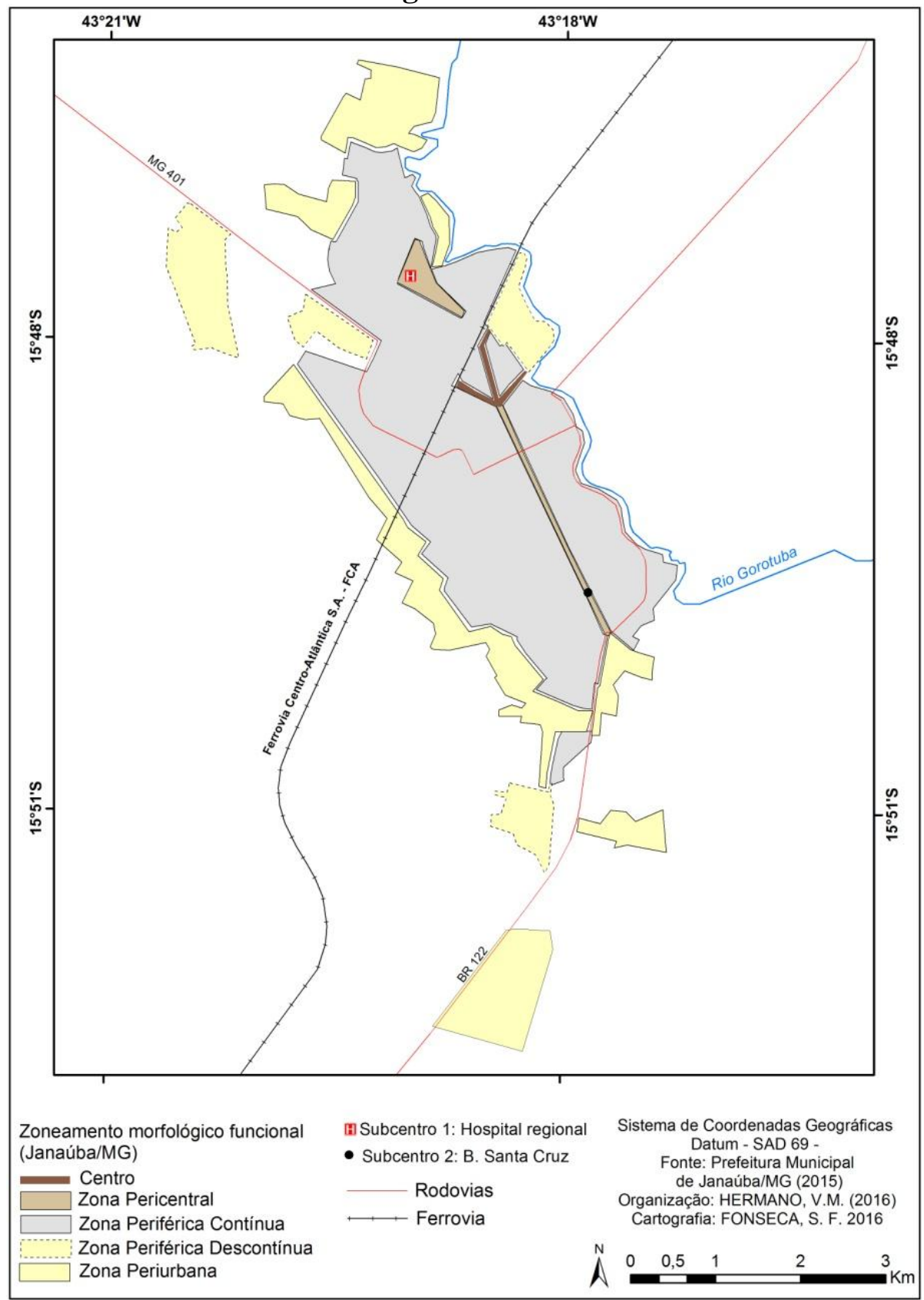

Fonte: Prefeitura Municipal de Janaúba, 2015. Organização: Fonseca e Hermano (2016).

Percebe-se que a atual estrutura do tecido de Janaúba/MG equivale às quatro categorias definidas pelo autor. Após a identificação das zonas urbanas da cidade de Janaúba/MG, foi constada sua adequação parcial ao modelo morfológico de Amorim Filho 
(2005). Sua conformação e sua estrutura estão orientadas pela presença dos equipamentos públicos, com forte influência das vias.

Todas as categorias do modelo foram reconhecidas em seu tecido, mas se registram singularidades, como a presença marcante da ruralidade (que remete a práticas e modos de vidas do espaço rural), a existência de dois subcentros e a linearidade das zonas central e parte da pericentral. Verificou-se que há similaridades com a morfologia de cidades pequenas (como a presença de poucos subcentros e a mudança brusca de uma zona para outra) e de cidades médias. A mudança morfológico-funcional ainda é incipiente; por isso ainda prevalecem algumas características de cidade de menor porte. A estrutura morfológica da cidade se assemelha ao modelo admitido na identificação da existência das quatro zonas urbanas, mas apresentando características morfológicas de cidades pequenas.

É importante ressaltar que o processo de urbanização da cidade apresenta características típicas de áreas periféricas do Nordeste do Brasil. Saneamento básico, pavimentação de qualidade e efetivo planejamento ainda são realidades distantes. Soma-se a esse fator a forte relação da cidade com o rural, tipicamente identificada em todas as análises realizadas neste estudo. Dessa forma, em Janaúba/MG, não se identificam padrões das áreas centrais, e a aplicação do modelo morfológico de cidades médias, pautada na contextualização regional, permite a aproximação entre o conceito e a realidade analisada.

\section{CONSIDERAÇÕES FINAIS}

O quadro natural da cidade, observado a partir da abordagem sistêmica, indica que alguns fatores puderam influenciar positivamente o processo de urbanização, como o relevo plano e a presença da Barragem Bico da Pedra, ratificando o sistema hídrico como agente interventor da organização e da expansão da cidade em regiões semiáridas. No interior desse sítio, a delimitação do perímetro urbano foi fortemente influenciada por fatores políticos e econômicos, muitas vezes negligenciando certas dinâmicas do geossistema local.

A estrutura natural sustenta um tecido conformado e orientado pela presença dos equipamentos públicos, com forte influência das vias. As categorias do modelo de Amorim Filho (2005) foram reconhecidas, porém a cidade apresenta a presença preponderante da 
ruralidade, a existência de poucos subcentros e a linearidade das zonas central e pericentral. Essa morfologia é um híbrido de feições de cidade pequena e média.

A identificação de aspectos da morfologia urbana Janaúba/MG permite identificar certas características da paisagem, como a forte presença de espaços vazios, em especial na zona periurbana, e a segregação sócioespacial identificada nas zonas descontínuas da cidade. A ocupação urbana em áreas de preservação permanente, como nas lagoas intermitentes e no entorno da barragem, prova que esse sítio e suas características geossistêmicas estão sendo, muitas vezes, negligenciados pelo processo de ocupação urbana. Levando-se em consideração a falta de planejamento e também o baixo desempenho econômico da região, pode-se afirmar que, atualmente, sua configuração exibe traços do avanço econômico e demográfico e do crescimento desequilibrado.

\section{REFERÊNCIAS}

ALMEIDA, José Antonio Pacheco. Aplicação da metodologia sistêmica ao estudo do sítio urbano de Feira de Santana-BA. Sitientibus, Feira de Santana, n. 22, p. 9-26, jan/jun, 2000. Disponível em:

http://www2.uefs.br/sitientibus/pdf/22/aplicacao_da_metodologia_sistemica.pdf. Acesso em: 02 mar. 2016.

AMORIM FILHO, Oswaldo Bueno. Um modelo de zoneamento morfológico-funcional do espaço intra-urbano das cidades médias de Minas Gerais. In:

AMORIM FILHO, Oswaldo Bueno; SENA FILHO, Nelson de. A morfologia das cidades médias. Goiânia: Ed. Vieira, 2005, p.35-80.

ARAUJO, Wellison Tatagiba de.Evolução urbana e dinâmica da paisagem em setores periféricos da metrópole paulistana: o caso de Taboão da Serra/SP. 2010, $231 \mathrm{f}$. Tese (Doutorado), Universidade de São Paulo , Programa de Pós-Graduação em Geografia Física, São Paulo, 2010. Disponível em: http://www.teses.usp.br/teses/disponiveis/8/8135/tde04102010-154430/pt-br.php. Acesso em: 11 agost. 2015.

BETTENCOURT, Luísa Catarina Freitas Andrade. A Morfologia Urbana da Cidade do Funchal e os seus espaços públicos estruturantes. 2007. 283 f. Dissertação (Mestrado), Universidade Lusófona de Humanidades e Tecnologias, Lisboa, 2007.

COSTA, S. A. P. A morfologia dos tecidos urbanos de influência inglesa da cidade de Nova Lima. Revista Paisagem e Ambiente, São Paulo, n. 25, p. 55-76, 2008.Disponível em: http://www.revistas.usp.br/paam/article/view/40259/43125. Acesso em: 04 agos. 2015.

DEL RIO, Vicente. Introdução ao Desenho Urbano. $3^{\circ}$ edi. São Paulo: PINI, 1990. 95 p. 


\section{HERMANO, V. M. \\ Morfologia urbana de Janaúba/MG}

DI MAURO, Claudio Antonio. A atualidade da visão de Ab'Sáber. Revista Sociedade e Natureza, Uberlândia, n. 1, ano 24, p. 7-20, jan/abr. 2012.Disponível em:

http://www.seer.ufu.br/index.php/sociedadenatureza/article/viewFile/14714/pdf.Acesso em : 21 agos. 2015.

DOLLFUS, Olivier. O espaço geográfico. 4. ed. São Paulo: Difusão Européia do Livro, 1982.121p.

ENDLICH, Angela Maria .Território e morfologia urbana em pequenas cidades: o que revelam?.Revista Geográfica de América Central, Chile, Especial EGAL, p. 3-25, 2011. Disponível em: http://www.revistas.una.ac.cr/index.php/geografica/article/viewFile/2275/2171. Acesso em : 26 agos. 2015.

GEORGE, Pierre. Geografia urbana.9edi. São Paulo: DIFEL, 1983. 236 p.

GONÇALVES, Felipe de Souza. A expansão urbana sobre o relevo do município de Sapucaí do Sul-RS. Dissertação 2013. 163f (Mestrado) Universidade Federal do Rio Grande do Sul Programa de Pós- Graduação em Geografia.. 2013. Disponível:

http://www.ufrgs.br/ppggea/pos/index.php?option=com_content\&view=article\&id=585:aexpansao-urbana-sobre-o-relevo-do-municipio-de-sapucaia-do-sulrs\&catid=43:defesamestrado\&Itemid=131. Acesso em: 24 de mar. 2016.

HERMANO, Vivian Mendes. Está ocorrendo uma crise da água no Projeto Gorutuba ? Boletim Eletrônico Centro de Estudos de Convivência com o Semi árido, Montes Claros, n. 7, ano 1, 2013. Disponível em: ttps://dl.dropboxusercontent.com/u/145303087/Esta ocorrendo uma crise de água no Projeto Gorutuba.pdf. Acesso em: 27 nov. 2014. Citar tese (2016)

Janaúba/MG: uma cidade médio no Norte de Minas Gerais. 2016. 242.f. Tese (Doutorado)-Pontifícia Universidade Católica de Minas Gerais, Programa de Pós-Graduação em Tratamento da Informação Espacial, Belo Horizonte, 2016. Disponível

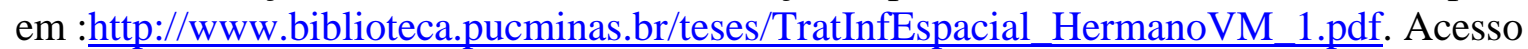
em: 03 jun.2017.

INSTITUTO BRASILEIRO DE GEOGRAFIA E ESTATÍSTICA - IBGE. Censo Demográfico Brasileiro de 2010. Rio de Janeiro, 2013.

JANAÚBA. Prefeitura Municipal. Lei n 1744 de 06 de Dezembro de 2007.Dispõe sobre a política de desenvolvimento urbano de Janaúba. Institui o Plano Diretor e dá outras providencias. Quadro de Aviso da Prefeitura Municipal de Janaúba 08 de Nov. 2007.153 p.

JANAÚBA. Prefeitura Municipal.Lei n 2104 de 23 de março de 2015. Altera artigos e inclui incisos da Lei ${ }^{\circ} 1744$ de 06 de Dezembro de 2007 que dispõe sobre a política de desenvolvimento urbano de Janaúba. Institui o Plano Diretor e dá outras providencias.

Quadro de Aviso da Prefeitura Municipal de Janaúba. 24 de mar. 2015. 9 p 
MARQUES, Jorge soares. Ciência geomorfológica. In: GUERRA, Antônio José Teixeira. CUNHA, Sandra. B. Geomorfologia uma atualização de bases e conceitos. Rio de Janeiro: Bertran Brasil, 2003. $5^{\circ}$ edi. p. 2-37.

MENEGUETT, I. K. S.; COSTA, Pereira S. A. The fringe -belt concept and planned new towns: a Brazilian case study. Urban Morphology , v. 19, p. 25-33, 2015. Disponível em: http://quapa.fau.usp.br/wordpress/wpcontent/uploads/2016/01/c10s01a04.pdf. Acesso em: 06 de abr. 2016.

OLIVEIRA, Danniel Madson Vieira. MOREIRA, Tiago Silva. RIBEIRO JUNIOR, José Arnaldo dos Santos. OLIVEIRA, Hudalet da Conceição. RODRIGUES, André Luís Soares. (Des/re) construção do tecido urbano: (processo de modernização e implosão-explosão urbana em São Luís / MA, no limiar do século XXI.In: Encontro Nacional de Geógrafos, XVL, 2010, Porto Alegre, Anais..., Disponível em:

file:///C:/Users/Positivo\%20pc/Downloads/Danniel\%20Madson\%20Vieira\%20Oliveira.pdf.A cesso: 23nov.2015.

REGO, Renato Leão. MENEGUETTI, Karin Schwabe. A respeito de morfologia urbana. Tópicos básicos para estudos da forma da cidade .Revista Acta, Maringá, v. 33, n. 2, p. 123127, 2011 .Disponível em:

http://periodicos.uem.br/ojs/index.php/ActaSciTechnol/article/viewFile/6196/6196. Acesso em: 09 nov. 2015.

SANTOS, Willian Rodrigues. HERMANO, Vivian Mendes. As praças de Janaúba: diagnóstico sócio ambiental e reflexões sobre a área verde urbana. Revista Multitexto, Montes Claros, v.3, n.2, p. 47-54, 2015. Disponível em:

http://www.ead.unimontes.br/multitexto/index.php/rmcead/article/view/143/86. Acesso: 01 fev. 2016

SILVEIRA, Gerlaine Soares da . OLIVEIRA, Igor Martins. Expansão urbana e degradação ambiental: o caso do bairro Camilo Prates. In: Simpósio Mineiro de Geografia, n.1, 2014, Alfenas, Anais....

Disponível em: http://www.unifal-

mg.edu.br/simgeo/system/files/anexos/Gerlaine\%20Soares\%20da\%20Silveira.pdf. Acesso em: 11 fev. 2015.

SOUZA Junior. Raimundo Mendes.Análise da vegetação da bacia do médio Gorutuba. 2002. 95 f. Trabalho de Conclusão de Curso (Graduação), Universidade Estadual de Montes Claros, Departamento de Ciências Agrárias, Janaúba, 2002.

VILLAÇA, Flávio. Espaço intraurbano no Brasil. $8^{\circ}$ Ed. São Paulo: Studio Nobel, 1998. $135 \mathrm{p}$. 


\section{Autora}

Vivian Mendes Hermano - Possui Graduação em Geografia pela Universidade Federal Uberlândia (UFU), Mestrado em Desenvolvimento Social pela Universidade Estadual de Montes Claros (UNIMONTES) e Doutorado em Tratamento da Informação Espacial pela Pontifícia Universidade Católica de Minas Gerais (PUC Minas). Atualmente é Professora do Departamento de Geociências da Universidade Estadual de Montes Claros (UNIMONTES).

Artigo recebido em: 09 de agosto de 2017. Artigo aceito em: 27 de setembro de 2017. 